\title{
GROSS REGIONAL DOMESTIC PRODUCT FORECASTS USING TREND ANALYSIS: CASE STUDY OF BANGKA BELITUNG PROVINCE
}

\author{
Nurmalita Oktaviana ${ }^{1}$, Nurisqi Amalia ${ }^{2}$ \\ Diploma in Applied Economics, Faculty of Economics and Business, Vocational School, \\ Universitas Gadjah Mada \\ Jl. Notonegoro No.1 Bulaksumur, Yogyakarta 55281 \\ ${ }^{1}$ nurmalitaoktaviana98@gmail.com \\ 2nurisqiamalia@gmail.com
}

Correspondence E-mail: nurmalitaoktaviana98@gmail.com

Received: May 2018; Accepted: October 2018

\begin{abstract}
Gross Regional Domestic Product (GRDP) is one of the important indicators to determine the economic conditions in the region. This study aims to forecast the Gross Regional Domestic Product (GRDP) of the Province of Bangka Belitung Islands which is dominated by tourism sector. This forecasting to be expected to give information to formulate a type of policy action that will be conducted by decision makers based on GRDP data. GRDP data are from the first quarter of 2010 to the fourth quarter of 2017 on the basis of constant prices in 2010. Data sources are obtained from Central Bureau of Statistics (BPS) of the Province of Bangka Belitung Islands. The forecasting method used is the research is trend analysis. The results of the GRDP forecasting of Bangka Belitung Province in the first quarter of 2018 to the fourth quarter of 2022 shows an increasing trend. It can be seen from historical data that shows an increasing trend as evidenced from the graph on linear trends. The increasing trend in GRDP of the Bangka Belitung Islands Province for the next five years is supported by government policies that prioritize the tourism sector. Consequently, by prioritizing the tourism sector, this will increase economic growth and can reduce GRDP dependency on mining sector, especially tin that has been continuously decreased.
\end{abstract}

Keywords : Forecasting; PDRB; Time Series; Trend Analysis

JEL Classification: E17, C53, C22

\section{INTRODUCTION}

The main variable used to determine the economic performance of a region is the level of economic growth over time (Gregory and Stuart, 1992). The value of Gross Domestic Product (GDP) at constant prices is used to calculate national economic growth (Rahardja and Manurung, 2001). GDP is defined as the value of goods and services produced in an area of the economy for a certain period of time (Abel, Andrew B, and Ben S. Bernake, 2001). An economy experiences growth if the amount of production of goods and services produced increases. A high and sustainable level of economic growth is a condition that is desired by every country and region. High growth rates will improve the welfare and prosperity of society as a whole. This is indicated by an increase in the availability of employment and income. Gross Regional Domestic Product (GRDP) is one of the important indicators for knowing the economic conditions in a country in a certain period of time. GRDP calculation becomes a very important part in macroeconomic, especially about the economic analysis of a region. The results of this GRDP calculation are used as a basis for measuring economic activity in an economic activity. These GRDP figures are used as mac- 
roeconomic indicators, as a basis for evaluating economic performance and formulating various policies. Gross Regional Domestic Product (GRDP) data is one of the important indicators to determine the condition of an area within a certain period, based on current prices and on the basis of constant prices. The movement of GRDP values over time is strongly influenced by political factors and government policies. GRDP data is based on a certain time sequence which is presented on an annual basis (longterm time series). Based on this indicator, it will be obtained an overview of the level of prosperity of people in a region.

The direction of movement of the Gross Regional Domestic Product (GRDP) is one of the government's ingredients in setting economic targets. One way to know the direction of movement can be done through forecasting. Forecasting is a way of projecting values in the past (known value) into the future. The method uses both mathematical models and subjective estimates. This often causes errors caused by the limitations of human abilities (Makridakis, et al., 1982). Forecasting is carried out to determine the movement of a data in the coming period as done by Jiang, et al. (2017) forecasting the growth of Gross Domestic Product (GDP) in China by using dynamic predictors and mixed frequency data. Dias, et al. (2015) estimate GDP growth before and after the economic and financial crisis in Portugal. Portugal's economy was badly hit by the crisis. Forecasting is very important in assessing relative performance during periods of economic crisis. $\mathrm{Xu}$, et al. (2018) forecasting using the GP-U-MIDAS model which results are very useful for policymakers in the US. In the same country, Modis (2013) states that GDP growth is considered a natural growth process that can be explained by the logistical growth equation. The S-shaped logistics pattern provides a good description and forecast for nominal and real GDP per capita in the US over the past 80 years. Jansen, et al. (2016) conducted a comparison between shortterm estimates of 12 statistical models and pro- fessional analysis using a set of monthly indicators. The results of these studies contain valuable information that can be used to improve predictions. Maity and Chatterje (2012) make predictions regarding the estimated growth rate of Indian GDP by using ARIMA. The results of the study indicate that only one period in autoregressive and moving averages are statistically significant. Furthermore, the absolute value of GDP that is estimated to show an increasing trend and its growth rate each reveals the opposite trend in the future. Wabomba, et al. (2016) conducted research related to Kenya's GDP forecasting for the next five years using ARIMA. The results of the estimates in the sample indicate that the relative values and predictions are in the range of $5 \%$ and the forecasting effect of this model is relatively efficient in making Kenya's annual GDP model. In all countries, data forecasting is very helpful for policymakers in determining the direction of their policies (Dovern, 2013). Dovern analyzed the frequency of estimated revisions and the factors that influenced them. The results show that each month on average $40 \%-50 \%$ of the forecasting results revise its estimates. Revision depends on a number of factors, such as predictions, business cycles, or strategic interactions between forecast. GDP forecasting analysis is also carried out in various studies in Indonesia. Satria, et al. (2015) forecast GDP and inflation in Indonesia. The projection results for the next five years show that $64 \%$ of models can explain variables well.

Forecasting Gross Regional Domestic Product (GRDP) of the Province of Bangka Belitung Islands by using the Trend is expected to provide an overview of economic growth and economic performance in the Province of Bangka Belitung Islands. Forecasting results can also be used as a basis for determining the amount of the budget and controlling costs. Forecasting of GDP of Bangka Belitung Province for 5 years from the first quarter of 2018 to the fourth quarter of 2022 was carried out to support the RPJMD of Bangka Belitung Prov- 
ince and to look at strategic issues and government policies focusing on economic growth. If forecasting is not done on GRDP for the future, the government will have difficulty predicting the possibilities in the future and not being right on target in determining or making policies.

This study aims to determine the value or forecasting of Bangka Belitung Province's Gross Regional Domestic Product (GRDP) data for preventing actions related to the type of policy that will be made by the decision maker (decision making). Research with the trend method predicts the GRDP of the Province of Bangka Belitung for the next 5 years, namely the first quarter of 2018 to the fourth quarter of 2022. The results show an increasing trend. This is not in line with research from Utama, et al. (2014). Forecasting the Gross Regional Domestic Product (PDRB) of Bali Province with the Box-Jenkins method which shows fluctuating results. This is because quarterly data is quite influenced by seasonal factors, such as tourist visits, weather and also the realization and development budget of the government.

The trend is a movement (tendency) up or down in the long run, which is obtained from the average change over time. The average change can increase and can reduce. If the average change increases, it is called a positive trend or trend that has an upward tendency. Conversely, if the average change is reduced, it is called a negative trend or a trend that has a downward trend. Trend illustrates the progress of time series data over a long period of time and has an ascending or descending tendency. This motion reflects the nature of continuity or a continuous state from time to time over a period of time. Because of the nature of this continuity, the trend is considered a stable movement so that in interpreting it can use a mathematical model. The trend can be either a straight line (regression/linear trend) or not straight (regression/non-linear trend) (Dajan, 1986). The advantage of the trend is that the forecast results are close to the actual value and are very good for long-term data while the weakness of this method is not suitable for short-term data use (Dajan, 1986).

\section{RESEARCH METHOD}

\section{Data}

The data used in this study are time series. Time series is a series of time will be known whether the events, events, symptoms, and variables observed are developing following regular patterns of development (Hanke, et al., 2003). The data used is the GRDP data of the Bangka Belitung Islands Province. This data is sourced from the Central Bureau of Statistics of the Province of Bangka Belitung Islands with a time period from the first quarter of 2010 to the fourth quarter of 2017. This type of data is secondary data because the data used is not obtained directly by the author.

\section{Data Analysis}

Data analysis is done using the trend method. Trend analysis is a long-term upward or downward trend from the average change over time. The data used is GRDP data in the quarter. The software used to process data is SPSS 20. Software According to Makridakis, et al. (1999) the selection of trend forecasting models can be done by comparing the coefficient of determination $\left(\mathrm{R}^{2}\right)$. The coefficient of determination $\left(R^{2}\right)$ measures how far the ability of the model in explaining the variation of the dependent variable and measuring the accuracy of a regression line applied to a group of research data. In general, the value of $\mathrm{R}^{2}$ can be defined as follows:

$$
R^{2}=\frac{\left(\sum \hat{Y}_{t}-\bar{Y}\right)^{2}}{\left(\sum Y_{t}-\bar{Y}\right)^{2}}
$$

Where:

$t \quad=$ time $/$ period

$\mathrm{Y}_{-} \mathrm{t} \quad=$ time series value in the $t$ period

$\hat{\mathrm{Y}} \_\mathrm{t} \quad=$ forecast value in the $t$ period

$\bar{Y} \quad=$ average time series value. The greater

the R2 value, the better the model / exact model obtained, which is about 0.7 to 1 .

The equation formula in the trend method is as follows:

$\mathrm{Y}=\mathrm{a}+\mathrm{bx}+\mathrm{e}$ 
Where:

$$
\begin{array}{ll}
\mathrm{Y} & =\text { GRDP } \\
\mathrm{a} & =\text { constant } \\
\mathrm{bx} & =\text { PDRBt }-1 \\
\mathrm{e} & =\text { error }
\end{array}
$$

\section{RESULTS AND DISCUSSION}

GRDP of Bangka Belitung Province on the basis of constant prices in 2010 per quarter during the first quarter of 2010 to the fourth quarter of 2017 experienced an increase as presented in Table 1. This shows that the data GRDP Bangka Belitung on a quarterly basis during 2010 - 2017 experienced positive growth.
The data above is GRDP data that starts from 2010 in the first quarter and ends in 2017 quarter IV. In this data, it is known that the GRDP of Bangka Belitung Province in the period of 2010 in the first quarter to 2017 in the fourth quarter has increased, can be seen from the highest GRDP in the fourth quarter of 2017 with a total of $12,672,009.37$.

Output Results of GRDP data of Bangka Belitung Province using SPSS 20 software in figure

\begin{tabular}{|c|c|c|c|}
\hline No & Year, (quarterly) & $\begin{array}{c}\text { GRDP } \\
\text { (million rupiah) }\end{array}$ & Growth (\%) \\
\hline 1 & 2010.1 & $8,592,658.23$ & \\
\hline 2 & 2010.2 & $8,808,349.94$ & 0.025101861 \\
\hline 3 & 2010.3 & $9,018,196.28$ & 0.02382357 \\
\hline 4 & 2010.4 & $9,142,699.72$ & 0.013805803 \\
\hline 5 & 2011.1 & $9,134,044.11$ & -0.000946724 \\
\hline 6 & 2011.2 & $9,478,236.39$ & 0.037682354 \\
\hline 7 & 2011.3 & $9,716,970.73$ & 0.025187633 \\
\hline 8 & 2011.4 & $9,684,739.07$ & -0.003317048 \\
\hline 9 & 2012.1 & $9,689,450.06$ & 0.000486434 \\
\hline 10 & 2012.2 & $9,962,560.97$ & 0.02818642 \\
\hline 11 & 2012.3 & $10,144,330.25$ & 0.018245236 \\
\hline 12 & 2012.4 & $10,308,564.86$ & 0.016189793 \\
\hline 13 & 2013.1 & $10,309,220.80$ & 6.36306E-05 \\
\hline 14 & 2013.2 & $10,508,920.08$ & 0.019370938 \\
\hline 15 & 2013.3 & $10,628,591.25$ & 0.01138758 \\
\hline 16 & 2013.4 & $10,744,124.96$ & 0.010870087 \\
\hline 17 & 2014.1 & $10,756,992.97$ & 0.001197679 \\
\hline 18 & 2014.2 & $11,017,029.10$ & 0.024173682 \\
\hline 19 & 2014.3 & $11,136,268.84$ & 0.010823221 \\
\hline 20 & 2014.4 & $11,249,148.61$ & 0.010136229 \\
\hline 21 & 2015.1 & $11,197,460.36$ & -0.004594859 \\
\hline 22 & 2015.2 & $11,455,280.50$ & 0.023024876 \\
\hline 23 & 2015.3 & $11,580,681.87$ & 0.010947036 \\
\hline 24 & 2015.4 & $11,728,881.25$ & 0.01279712 \\
\hline 25 & 2016.1 & $11,582,514.86$ & -0.012479143 \\
\hline 26 & 2016.2 & $11,895,095.64$ & 0.026987298 \\
\hline 27 & 2016.3 & $12,063,444.17$ & 0.014152768 \\
\hline 28 & 2016.4 & $12,309,765.99$ & 0.020418864 \\
\hline 29 & 2017.1 & $12,326,039.26$ & 0.00132198 \\
\hline 30 & 2017.2 & $12,511,643.00$ & 0.015057857 \\
\hline 31 & 2017.3 & $12,498,059.28$ & -0.001085686 \\
\hline 32 & 2017.4 & $12,672,009.37$ & 0.013918168 \\
\hline
\end{tabular}
2 and figure 2.

Table 1. Bangka Belitung Province's Gross Regional Domestic Product Based on Constant Prices in 2010, from Quarter I of 2010 to Quarter IV of 2017

Source: Author estimation (2018), data are obtained from BPS Bangka Belitung Province. 
Table 2. Summary Output

\begin{tabular}{ccccc}
\hline $\begin{array}{c}\text { Model } \\
\text { Summary }\end{array}$ & $\mathbf{R}$ & R Square & Adjusted R Square & $\begin{array}{l}\text { Std. The error of the Esti- } \\
\text { mate }\end{array}$ \\
\hline 1 & $.997 a$ & .994 & .994 & 96221.64555 \\
\hline
\end{tabular}

a. Predictors: (Constant). Quarterly

Source: Author estimation (2018)

Table 3. Coefficients Regression

Coefficients $^{a}$

\begin{tabular}{lllllll}
\hline \multirow{2}{*}{ Model } & \multicolumn{2}{c}{ Unstandardized Coefficients } & \multicolumn{2}{c}{$\begin{array}{c}\text { Standardized } \\
\text { Coefficients }\end{array}$} & T & Sig. \\
\cline { 3 - 6 } & \multicolumn{2}{c}{ B } & \multicolumn{2}{c}{ Std. Error } & Beta & \\
\hline \multirow{2}{*}{1} & (Constant) & 8648738.545 & 34832.819 & 248.293 & .000 \\
& PDRB $_{\mathrm{t}-1}$ & 127068.824 & 1842.259 & .997 & 68.974 & .000 \\
\hline
\end{tabular}

a. Dependent Variable: PDRB

Source: Author estimation (2018)

Based on table 2 above it is known that the R-value of 0.997 which is closed to 1 means that between the independent variable, in this case, the GRDP of the previous year has a close relationship with the dependent variable GRDP. The value of R-Square is 0.994 which means the variation of GRDP can be explained by the time period of the transaction of 0.994 or $99.4 \%$ and the remaining $0.6 \%$ is explained by other variables outside the model.

Linear Trend Method will be used to forecast GRDP data in Bangka Belitung Province for the next five years quarterly using SPSS 20 . Software Based on the regression coefficient table above it can be seen that the significant value <alpha means that the independent variable (PDRBt- 1 ) affects the dependent variable (GRDP).

Table 4 shows the forecasting data of the Gross Regional Domestic Product of the Bangka Belitung Islands Province in 2018 in the first quarter to 2022 in the fourth quarter along with growth in percent for the first quarter to the fourth quarter of each year.

Table 4. Results of Forecasting the Gross Regional Domestic Product of Bangka Belitung Province According to Constant Prices in 2010, from Quarter I of 2018 to Quarter IV of 2022

\begin{tabular}{cccc}
\hline No & Year, Quarterly & PDRB (million rupiahs) & Growth (\%) \\
\hline 1 & 2018.1 & $12,842,009.74$ & 0.009894777 \\
2 & 2018.2 & $12,969,078.56$ & 0.009797830 \\
3 & 2018.3 & $13,096,147.39$ & 0.009702763 \\
4 & 2018.4 & $13,223,216.21$ & 0.009609524 \\
5 & 2019.1 & $13,350,285.03$ & 0.009518061 \\
6 & 2019.2 & $13,477,353.86$ & 0.009428321 \\
7 & 2019.3 & $13,604,422.68$ & 0.009340258 \\
8 & 2019.4 & $13,731,491.50$ & 0.009253826 \\
9 & 2020.1 & $13,858,560.33$ & 0.009168977 \\
10 & 2020.2 & $13,985,629.15$ & 0.009085671 \\
11 & 2020.3 & $14,112,697.98$ & 0.009003864 \\
12 & 2020.4 & $14,239,766.80$ & 0.008923519 \\
13 & 2021.1 & $14,366,835.63$ & 0.008844593 \\
14 & 2021.2 & $14,493,904.45$ & 0.008767052 \\
15 & 2021.3 & $14,620,973.27$ & 0.008690860 \\
16 & 2021.4 & $14,748,042.10$ & 0.008615979 \\
18 & 2022.1 & $14,875,110.92$ & 0.008542379 \\
19 & 2022.2 & $15,002,179.75$ & 0.008470024 \\
20 & 2022.3 & $15,129,248.57$ & 0.008398885 \\
\hline
\end{tabular}

Source: Author estimation 


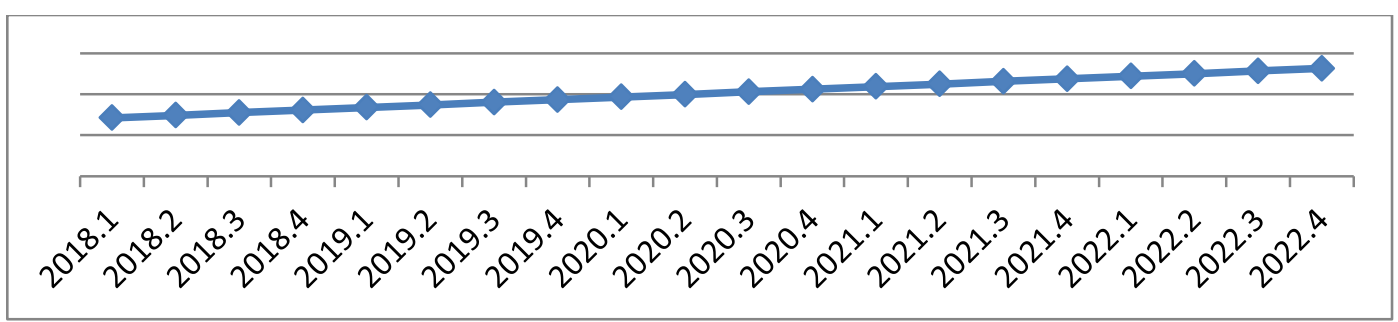

Figure 1. Province PDRB Forecasting Results of Bangka Belitung Year 2018 Quarter I - 2011 Quarter IV

Source: Author estimation (2018)

Based on the table, it is known that the results of the forecasting of the Gross Regional Domestic Product of the Bangka Belitung Islands Province from 2018 quarter I up to 2022 quarter IV using the trend method experienced an increase seen from the table of GRDP.

The forecasting results of the Gross Regional Domestic Product of the Bangka Belitung Islands Province are used as an illustration to see the possibilities that occur in the future. With the prediction about the possibilities that occur in the coming period, the government has a reference for making policies.

Figure 1 shows the results of forecasting the Gross Regional Domestic Product (GRDP) of the Bangka Belitung Islands Province in 2018 the first quarter to 2022 the fourth quarter shows an increasing trend. Bangka Belitung Province is one of the provinces in Indonesia which has mining natural wealth (Sujitno, 2007). Statistical data from the United States Bureau of Mines (USBM) records that Malaysia has tin mining reserve a number 1 (one) and followed by Indonesia which has tin mining reserves around 800,000 tons. This has the potential to increase foreign exchange for the national economy in Indonesia.

The mining sector is very influential on GRDP growth in Bangka Belitung Province. The sector is able to contribute around $13 \%$ to the provincial economy with its main commodity being tin mining. The economic growth of the Bangka Belitung Islands Province continues to experience a slowdown during the period 2011 - 2014. The economic growth of the Bangka Belitung Islands Province is slowing down due to the decline in the mining sector. Tin mining is the main product of natural resources in Bangka Belitung Province. The decline in the contribution from the mining sector was due to lower demand from the tin metal industry. In addition to declining demand, the selling price also decreased.

With the increasingly intense issue of environmental damage as a result of mining activities, mining permits are increasingly tightened. Bangka Belitung Islands Province has a damaged and very critical land condition compared to other provinces, reaching Rp1,053,253.19 hectares or $62 \%$ of the land area of the Bangka Belitung Islands Province (WALHI Nasional - WALHI Bangka Belitung Islands). The diminishing supply of tin commodities requires the alternative sector to support the economy of the Bangka Belitung Islands Province. To reduce the dependence of the Bangka Belitung Province on the mining sector, the government is trying to improve the tourism sector to increase economic growth because tourism potential in the Province of Bangka Belitung Islands is very large. The government's efforts have been stated in the RPJMD of the Bangka Belitung Islands Province in 2017-2022 and also become one of the government's priority programs. There are 11 priority programs that will be implemented in the Regional Development Program 2017-2022. There are 3 (three) main priorities that are of particular concern, namely the development of pepper, tourism and mining management that pay attention to the environment. 
In the Province of Bangka Belitung Islands tourism development is one of the activities that in recent years have been carried out more seriously than in previous years. Tourism has even been designated as one of the leading sectors in the face of the post-tin Bangka Belitung Islands. After more than three centuries tin was mined in Bangka Belitung and became the backbone of the regional economy then tin mining is estimated to be entering a "sunset industry" so that other sectors are needed as an alternative, namely tourism and marine fisheries. To encourage the acceleration of tourism development, the provincial government of the Bangka Belitung Islands launched the Tourism Visit Year program to the 2010 Bangka Belitung Islands called the Visit Bangka Belitung Archipelago 2010, abbreviated as Visit Babel Archi (VBA) 2010. The program, which began with the launching of the Minister of Culture and Tourism in Belitung at the end of 2009, contains a number of agenda activities in Bangka Belitung which are expected to attract tourists to visit. Likewise in 2011, an international national scale event was held, namely Sail Wakatobi Belitong (SWB) in 2011, where participants who participated in this activity were yachter fans from various countries. Tourism development in a country will encourage and accelerate economic growth. In the framework of regional development, the tourism sector plays a decisive role and can be a catalyst to gradually improve the development of other sectors. The success of the development of the tourism sector means that it will increase its role in regional revenues, where tourism is the main component (Pleanggra and Yusuf, 2003). The tourism sector is one sector that has a contribution in the employment absorption. The arrival of tourism to an area will open opportunities for the community to open a business so that the opportunity will provide an opportunity for the local community to work so that the community will earn income from the work (Projogo, 1976). Tourism is one of several major industries in the world, with a contribution to the total value of the world's Gross Domestic Product (GDP) reaching 9\% and the number of workers absorbed in this industry reaching 200 million people (UNWTO. Sustainable Tourism for Development Guidebook Madrid, Spain: World). Notes from the World Travel Organization (WTO) indicate that within the next few decades, tourism as an industry will develop at a rate that exceeds other types of industries. In 2012, the number of tourist trips to various world tourist destinations reached 1,035 billion; a growth of $5.6 \%$ per year. A number of research conducted in various world tourism destinations, generally indicates that tourism as an industry will provide positive benefits to the regional economy and the potential for negative benefits on the local socio-cultural and environmental dimensions (Sebele, 2010; Aref, 2011). Tourism can open employment opportunities, improve community welfare, create business opportunities and entrepreneurs in basic industries and support tourism. On the different side, tourism has a tendency to exploit natural resources and the cultural potential of local communities (Untong et al., 2010). The Province of Bangka Belitung Islands has an amazing natural beauty of the beach, besides that, it also has a variety of tourist attractions such as water tourism. Nature tourism, cultural tourism, and special interest tours. This diversity can provide an alternative choice of travel that is more varied for tourists. The visit of local tourists and foreign tourists to Bangka Belitung has quite favorable prospects because it greatly helps the improvement of the community's economy. Efforts to develop the tourism sector in the Bangka Belitung Islands are progressing as seen from the increasing number of tourism facilities, transportation, communication and the increasing number of tourists. However, faster acceleration is needed to spur the preparation of the tourism sector in the Bangka Belitung Islands, because mines, especially tin and minerals will surely run out. 
Table 5. Data of Foreign Tourist Visits and Archipelago Tourists to Tourism Objects in Bangka Belitung Islands Province in 2011-2014.

\begin{tabular}{|c|c|c|c|c|c|c|c|c|c|}
\hline \multirow[t]{2}{*}{ Year } & \multicolumn{3}{|c|}{ Target } & \multicolumn{6}{|c|}{ Realization } \\
\hline & $\begin{array}{l}\text { Domestic } \\
\text { Tourists }\end{array}$ & $\begin{array}{l}\text { International } \\
\text { Tourists }\end{array}$ & Total & Tourists & $\%$ & $\begin{array}{l}\text { International } \\
\text { tourists }\end{array}$ & $\%$ & Number & $\%$ \\
\hline 2006 & 75,131 & 2,324 & 77,455 & 67,935 & 90.42 & 447 & 19.23 & 68,328 & 88.29 \\
\hline 2007 & 77,686 & 2,403 & 80,089 & 62,271 & 80.16 & 148 & 6.16 & 62,419 & 77.94 \\
\hline 2008 & 80,192 & 4,221 & 84,413 & 78,700 & 98.14 & 380 & 9.00 & 79,080 & 93.68 \\
\hline 2009 & 84,523 & 4,449 & 88,972 & 93,816 & 111.00 & 622 & 13.98 & 94,438 & 106.14 \\
\hline 2010 & 89,087 & 4,689 & 93,776 & 136.022 & 152.68 & 701 & 14.95 & 136,723 & 145.80 \\
\hline
\end{tabular}

Source: Author estimation, data obtained from BPS of the Bangka Belitung Province and the RIPPDA of Bangka Belitung Island Province.

In other words, the tourism sector as a leading sector in the region must be prepared more quickly before the end of the role of tin mining.

Based on Table 5 can be seen the number of tourist visits in the Bangka Belitung Islands. In 2007 there was a decrease in the number of tourist visits, but for the following years, an increase occurred. If referring to the tourist targets listed in the Regional Tourism Development Master Plan (RIPPDA) document, the target number of domestic tourist visits can be said to have been exceeded, but the target number of foreign tourist arrivals is still not reached. The target of tourists in RIPPDA who came to Bangka Belitung Islands in 2010 was 93,776 people divided into domestic tourists as many as 89,087 people and foreign tourists as many as 4,689 people. Of these targets, the achievements in 2010 were for domestic tourists 136,022 people or $152.6 \%$ of the target while number of foreign tourist only 701 people or only $14.95 \%$ of the target in RIPPDA. If tourist visits in the Bangka Belitung Islands Province continue to increase, it does not rule out the possibility that the tourism sector can replace the contribution to the GRDP of the Bangka Belitung Islands Province.

Figure 2 shows the results of the figure where the blue line is the observation data of the Gross Regional Domestic Product (GRDP) of Bangka Belitung Province in the period of 2010 I quarter to 2017 IV quarter, and the green line is the result of GRDP forecasting 2018 2022.

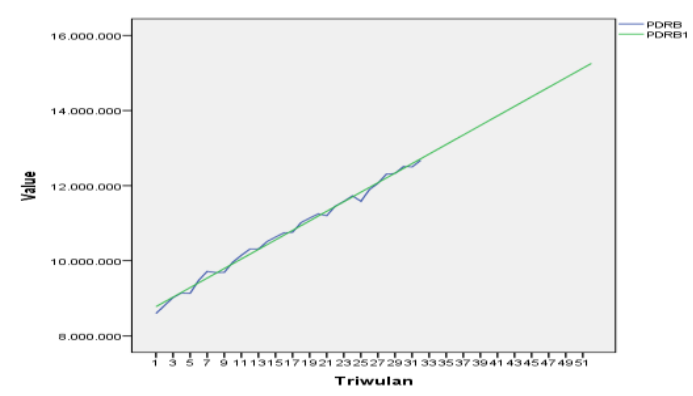

Figure 2. Figure of GRDP Forecasting Results in Bangka Belitung Province

Source: Data Processed

It is known that green lines (forecasting lines) follow the rising pattern of the blue lines or observation data.

Based on the data above, then the researchers do the next step, namely the data processing process with the help of SPSS 20 software. Before making a forecast, it must be known in advance the type of data pattern used. The results of the plot of data processed with SPSS 20 software are shown in Figure 3.

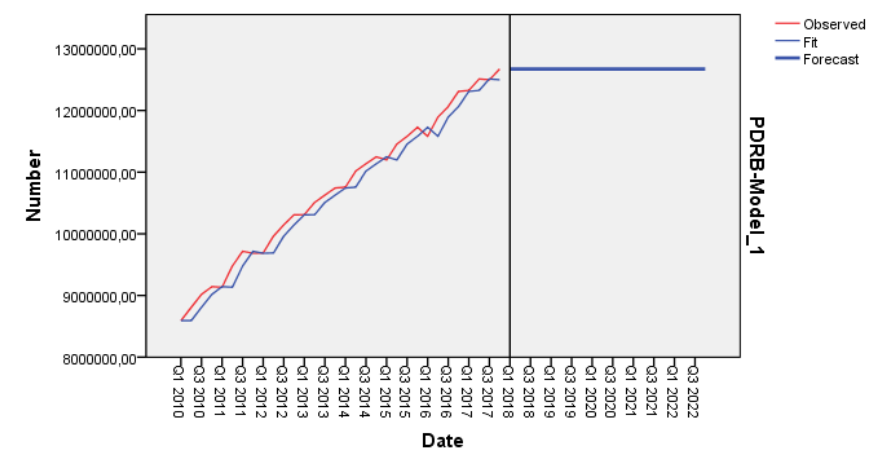

Figure 3. Linear Trend Charts and Gross GRDP Forecasting in Bangka Belitung Province

Source: Data Processed 
In figure 3 above, it can be seen that the GRDP data of Bangka Belitung Province has an upward trend pattern which means that it has experienced an increase in GRDP in 2010 in the first quarter to 2022 quarter IV. Observation data from PDRB in the first quarter of 2010 to the fourth quarter of 2017 shows an upward pattern which is depicted with a red line. For the blue line is the result of GRDP forecasting in 2018 in the first quarter up to the fourth quarter of 2022. Both lines have an uptrend pattern which means that the forecasting data follows the pattern of observation data, which is increasing every quarter of the year.

\section{CONCLUSION}

Forecast results using a trend have a type of data that has an up-trend pattern, meaning that the GRDP of the Bangka Belitung Islands Province for the next five years, namely from 2018 in the first quarter and ending in the forecast period of the fourth quarter of 2022, has increased. The increase in GRDP of the Bangka Belitung Islands Province for the next five years is supported by government policies that prioritize the tourism sector. Consequently, by prioritizing the tourism sector, this will increase economic growth and can reduce GRDP dependency on mining sector, especially tin that has been continuously decreased.

\section{REFERENCES}

Abel, A.B., and Bernake, B.S. (2001). Macroeconomics. New York: Addison Wesley Longman. Inc.

Aref, F. (2011). The Effects of Tourism on Quality of Life: A Case Study of Shiraz. Iran. Life Science Journal, 8(2), 26-30.

Badan Perencanaan Pembangunan Daerah. (2018). Rencana Pembangunan Jangka Menengah Daerah (RPJMD) Provinsi Bangka Belitung Tahun 2017-2022. (Online) Belitung. Available from http://bappeda.babelprov.go.id (Accessed: 29th March, 2018).
Badan Pusat Statistik Provinsi Bangka Belitung. (2018). PDRB Triwulanan Provinsi Kepulauan Bangka Belitung Atas Dasar Harga Konstan Menurut Lapangan Usaha (Million Rupiahs) 2010-2017. (Online) Jakarta. Available from https://babel.bps.go.id/ (Accessed: 29th, March 2018).

Bangka Belitung Provinsi. (2018). Pertumbuhan Ekonomi Tantangan Terbesar Provinsi Bangka Belitung. (Online) Belitung. Available from http://babelprov.go.id (Accessed: 29th, March 2018).

Bappenas. (2018). Sistem Informasi dan Manajemen Data Dasar Regional. Analisis Pembangunan Wilayah Provinsi Bangka Belitung. (Online) Jakarta. Available from http://simreg.bappenas.go.id. (Accessed: 29th, March 2018).

Dajan, A. (1986). Pengantar Metode Statistik. Jilid I. Jakarta: LP3ES.

Dias, F., Pinheiro, M., and Rua, A. (2015). Forecasting Portuguese GDP with factor models: Pre- and post-crisis evidence. Economic Modelling 44, 266-272.

Dovern, J. (2013). When are GDP forecasts updated? Evidence from a large international panel. Economics Letters 120, 521524.

Gregory, P.R., and Stuart, R.C. (1992). Comparative Economic'System. Fourth Edition. New Jersey: Houghton Mifflin Company.

Hanke, John, et.al. (2003). Peramalan Bisnis. Jakarta: Pearson Education Asia Ptc. Ltd dan PT. Pren Hallindo.

Jansen, W.J., Jin, X., and de Winter., J.M. (2016). Forecasting and nowcasting real GDP: Comparing statistical models and subjective forecasts. International Journal of Forecasting 32, 411-436.

Jiang, Y., Guo, Y., and Zhang, Y. (2017). Forecasting China's GDP growth using dynamic factors and mixed-frequency data. Economic Modelling 66, 132-138.

Makridakis, S., Andersen, A., Carbone, R., Fildes, R., Hibon, M., Lewandowski, R., Newton, J., Parzen, E. and Winkler, R.. (1982) The accuracy of extrapolation (time series) methods: Results of a fore- 
casting competition. Journal of the Royal Statistical Society. Series D (The Statistician), 34(2), 261-262.

Maity, B., and Chatterjee, B. (2012). Forecasting GDP growth rates of India: An empirical study. International Journal of Economics and Management Sciences, 1(9), 5258.

Modis, T. (2013). Long-term GDP forecasts and the prospects for growth. Technological Forecasting \& Social Change 80, 15571562.

Pleanggra, F. and Yusuf, E.A. (2012). Analisis Pengaruh Jumlah Obyek Wisata, Jumlah Wisatawan dan Pendapatan Perkapita Terhadap Pendapatan Retribusi Obyek Pariwisata 35 Kabupaten/ Kota di Jawa Tengah Doctoral dissertation. Fakultas Ekonomika dan Bisnis. Universitas Diponegoro.

Projogo, M.J. (1976): Pengantar Pariwisata Indonesia; Jakarta: Direktorat Jenderal Pariwisata.

Rahardja, P., and Manurung, M. (2001). Teori Ekonomi Makro: Suatu Pengantar. Jakarta: LP FE Universitas Indonesia.

Sebele, L.S. (2010). Community-Based Tourism Ventures. Benefits and Challenges: Khama Rhino Sanctuary Trust. Central District. Botswana. Tourism Management, 31, 136-146.

Satria, I., Yasin, H., and Suparti. (2015). Proyeksi Data Produk Domestik Bruto (PDB) dan Foreign Direct Investment (FDI) Menggunakan Vector Autoregressive (VAR). Jurnal Gaussian, 4(4), 895905.

Sujitno, S. (2007). Dampak Kehadiran Timah Indonesia Sepanjang Sejarah Pada Aspek Politik Ekonomi Sosial Budaya. Jakarta: Cempaka Publishing.

Utama, M.S. and Wirawan, I.G.P.N. (2014). Model Box-Jenkins Dalam Rangka Peramalan Produk Domestik Regional Bruto Provinsi Bali. Universitas Udayana. Jurnal Buletin Studi Ekonomi, 19(1), 92-104.

Untong, A., Kaosa-ard, M., Ramos, V., Sangkakorn, K., and Rey-Maquieria, J. (2010).
Factors Influencing Local Resident Support for Tourism Development: A Structural Equation Model. The APTA Conference 2010. Macau.

UNWTO. (2013). Sustainable Tourism for Development Guidebook. Madrid. Spain: World Tourism Organization.

Wabomba, M.S., Mutwiri, M.P., and Frederick, F. (2016). Modeling and Forecasting Kenyan GDP Using Autoregressive Integrated Moving Average (ARIMA). Science Journal of Applied Mathematics and Statistics, 4(2), 64-73.

Xu. Q., Zhuo, X., Jiang, C., Liu, X. and Liu, Y. (2018). Group penalized unrestricted mixed data sampling model with application to forecasting US GDP growth. Economic Modelling 75, 221-236. 